\title{
Influence of Precise Land Development Technique on Soil Moisture Variability and Water Saving in Groundnut (Arachis hypogaea L.) Production
}

\author{
P. S. Kanannavar*, P. Balakrishnan and S. K. Upadhyaya \\ (Agri. Engg.) University of Agricultural Sciences, Dharwad, India \\ *Corresponding author
}

\section{A B S T R A C T}

\begin{tabular}{|l|}
\hline Ke y w o r d s \\
Groundnut \\
production, Precise \\
land levelling, \\
Water saving, \\
Traditional land \\
levelling, Soil \\
moisture variability \\
\hline Article Info \\
\hline $\begin{array}{l}\text { Accepted: } \\
18 \text { April } 2020 \\
\text { Available Online: } \\
\text { 10 May } 2020\end{array}$ \\
\hline
\end{tabular}

For efficient irrigation and higher yields precise laser land development is often advocated as the most effective water saving method. Land levelling, having impact on moisture storage and distribution conditions in the field both spatially and temporally, affects crop growth and yields. Hence, the field experiments were conducted in the research farm of the University of Agricultural Sciences (UAS) Raichur to investigate the effect of laserland levelling on the performance of groundnut (Arachis hypogaea L.) and also the effect of laser levelling on spatial and temporal variability of topographic conditions, irrigation and water use efficiencies. The treatments comprised levelling methods $v i z ., \mathrm{L}_{1}$ - laser land levelling with $0.2 \%$ slope, $\mathrm{L}_{2}$-laser land levelling with $0.4 \%$ slope, $\mathrm{L}_{3}$-traditional land levelling method and $\mathrm{L}_{4}$ - no levelling and irrigation methods viz., $\mathrm{I}_{1}$ - border strip irrigation and $\mathrm{I}_{2}$-check basin irrigation. The soil moisture studies after 24 hours of a rainfall event indicated that both the average soil moisture in soil depth $(0-15 \mathrm{~cm})$ and uniformity coefficient $\left(\mathrm{C}_{\mathrm{u}}\right)$ of its distribution were maximum (45.14 and 94.84 and 41.18 and 93.49 per cent) in 0.2 and $0.4 \%$ slope laser levelled plots $\left(\mathrm{L}_{1}\right.$ and $\left.\mathrm{L}_{2}\right)$, respectively. Traditional levelling method $\left(\mathrm{L}_{3}\right)$ recorded lower values of 35.19 and $83.33 \%$, while the same were least $(25.10$ and $77.11 \%)$ in unlevelled control plot $\left(\mathrm{L}_{4}\right)$. The standard deviation indicating spatial variability of soil moisture was minimum (2.79 and $3.46 \%$ ) with more uniform and higher moisture conservation in laser levelled plots followed by $7.22 \%$ in traditional levelled plot and the maximum of 8.89 per cent in unlevelled plot. The trend was same even after 7 days of rainfall events in respect of soil moisture storage, depletion and uniformity coefficient. The average uniformity coefficient of laser levelled plots was the highest $(89.77 \%)$ followed by $\mathrm{L}_{3}(77.67 \%)$ and the least in case of $\mathrm{L}_{4}(73.15 \%)$. The results also showed that laser levelling could decrease the water application rates considerably when compared to traditional and no levelling. The highest per cent water saving was observed in laser levelled fields with 0.4 $\%$ slope (28.03 and $40.50 \%)$ followed by laser levelled fields with $0.2 \%$ slope (23.61 and 36.89\%) over traditional and unlevelled fields respectively. Mean of both the laser land levelling cases registered $63.68 \%$ more water productivity over traditional leveling establishing the fact that laser levelling saves valuable water with the highest water productivity of groundnut production.

\section{Introduction}

In India, groundnut (Arachis hypogaea L.) is grown in an area of $6.4 \mathrm{M}$ ha with a production of $7.21 \mathrm{M} \mathrm{t}$. It accounts for 28.44 $\%$ of the total world groundnut area and contributes 24.69 per cent to the world production. Six major groundnut growing states are Gujarat, Andhra Pradesh, Tamil
Nadu, Rajasthan, Karnataka and Maharashtra which contribute to $90 \%$ of total groundnut area of India. Karnataka ranks fifth in the country with a production of $0.38 \mathrm{M}$ trom an area of $0.76 \mathrm{M}$ ha (Anon., 2012). The average productivity of groundnut in India is $1,125 \mathrm{~kg}$ $\mathrm{ha}^{-1}$, which is far below the world's average pod yield of $1,449 \mathrm{~kg} \mathrm{ha}^{-1}$. Where irrigation is possible, higher groundnut yields are 
achieved and there has been a substantial increase in area under irrigated groundnut in India during the past five decades.

For efficient irrigation and higher yields precise laser land development is often advocated as the most effective water saving method. Laser Land levelling increases crop germination and yields and improves water distribution (Rickman, 2002). It also enhances irrigation efficiency (Sattar et al., 2003, Rajput et al., 2004) and increases cultivable land area up to 3-5 per cent (Jat et al., 2005). The precise land levelling methods have resulted in smoother soil surface, reduction in time and water required to irrigate the field, more uniform distribution of water in the field, more uniform moisture environment for crops, more uniform germination and growth of crops. The foremost objective of the laser land levelling is to enhance efficiency of irrigation water, which ultimately saves water leading to higher water productivity. However, no such data on water saving and water productivity impacts of land levelling in groundnut production was available in India in general and Karnataka in particular. Therefore, a study was initiated to determine the effect of laser land leveling soil moisture variability and water saving in groundnut production.

\section{Materials and Methods}

The field experiments in the medium textured soils of University of Agricultural Sciences (UAS) Raichur during kharif seasons of 2013 and 2014 were conducted to see the effect of laser land levelling techniques on water saving in groundnut production. The field experiment was laid out on one ha field with split plot design with levelling methods viz., $\mathrm{L}_{1}$-laser land levelling with $0.2 \%$ slope, $\mathrm{L}_{2}-$ laser land levelling with $0.4 \%$ slope, $\mathrm{L}_{3}-$ traditional land levelling method and $\mathrm{L}_{4}-\mathrm{no}$ levelling (control) as main treatments and irrigation methods viz., $\mathrm{I}_{1}$-border strip irrigation and $\mathrm{I}_{2}$-check basin irrigation as subtreatments. It was replicated four times.

\section{Laser unit}

A commercial unit of laser guided land leveller (Model GL-522) was used for the study and one directional slopes of 0.2 and $0.4 \%$ were given. Laser levelling unit consist main components viz., Laser transmitter, laser receiver, hydraulic valve and control box and its operational view is shown in Fig. 1. The layout details of field experiment are shown in Fig. 2.

\section{Soil moisture variability}

Land levelling affects moisture storage and distribution conditions viz., mean, standard deviation (SD) and uniformity co-efficient $\left(\mathrm{C}_{\mathrm{u}}\right)$ in the field both spatially and temporally. Soil moisture in depths of $0-15 \mathrm{~cm}$ was measured on volumetric basis using a precise and calibrated TDR (Time Domain Reflectometer). The soil moisture measurement was done after 24 hours of rainfall and 7 days of rainfall event. The rainfalls received during these days were 18.6 and $29.2 \mathrm{~mm}$ and 15.6 and $16 \mathrm{~mm}$, respectively. The spatial and temporal variability of soil moisture $(0-15 \mathrm{~cm})$ due to rainfall events as affected by different land levelling methods is given in Table 1. It indicates soil moisture varied both spatially and temporally. The mean soil moisture content (\%) on volume basis in different locations of all levelling treatments taken by TDR showed that soil moisture $(0-15 \mathrm{~cm})$ in the same treatments was distributed and varied differently.

After a day of rainfall event, both the mean soil moisture and uniformity co-efficient $\left(\mathrm{C}_{\mathrm{u}}\right)$ of its distribution were maximum in plots levelled by laser leveller. 
They were 45.14 and 94.84 and 41.18 and 93.49 per cent in plots with laser levelling 0.2 and 0.4 per cent slope i.e. $\mathrm{L}_{1}$ and $\mathrm{L}_{2}$ respectively. The same were 35.19 and 83.33 per cent for traditional plot $\left(\mathrm{L}_{3}\right)$. The lowest mean soil moisture content (\%) and uniformity co-efficient $\left(\mathrm{C}_{\mathrm{u}}\right)$ of 32.29 and 77.11 were observed in Control plot $\left(\mathrm{L}_{4}\right)$. The standard deviation data indicated spatial variability was minimum (2.79 and 3.46) in laser levelled plots $\left(\mathrm{L}_{1}\right.$ and $\left.\mathrm{L}_{2}\right)$ followed by traditional levelled plot (7.22). The highest standard deviation of 8.89 was observed in $\mathrm{L}_{4}$ indicating higher spatial variability of soil moisture storage. After one week of rainfall event, the same trend was observed in respect of soil moisture storage, depletion and uniformity coefficient. The mean of uniformity coefficient of laser levelled plots (both $\mathrm{L}_{1}$ and $\mathrm{L}_{2}$ ) was the highest $(89.77 \%$ ) followed by $\mathrm{L}_{3}(77.67 \%)$. The lowest uniformity coefficient $(73.15 \%)$ was observed in $\mathrm{L}_{4}$.

\section{Quantity of water used $\left(\mathrm{m}^{3} \mathrm{ha}^{-1}\right)$ and water saving}

The pooled data regarding irrigation water used $\left(\mathrm{m}^{3} \mathrm{ha}^{-1}\right)$ and per cent water saving as influenced by different land levelling and irrigation methods for groundnut production are presented in Table 2.

The plot levelled using laser leveller with 0.4 per cent slope $\left(\mathrm{L}_{2}\right)$ required the lowest quantity of irrigation water of $1562.88 \mathrm{~m}^{3} \mathrm{ha}^{-}$ ${ }^{1}$. It was followed by plot levelled using laser leveller with 0.2 per cent slope $\left(1658.88 \mathrm{~m}^{3}\right.$ $\left.\mathrm{ha}^{-1}\right)$ and traditional levelled plot $\left(2171.52 \mathrm{~m}^{3}\right.$ $\left.\mathrm{ha}^{-1}\right)$. The control plot with no levelling used the highest quantity of water of $2628.48 \mathrm{~m}^{3}$ $\mathrm{ha}^{-1}$.

The highest per cent water saving was observed in the plot with 0.4 per cent slope, $\mathrm{L}_{2} 40.54$ per cent, when compared with unlevelled plot $\left(\mathrm{L}_{4}\right)$. Whereas, the plot with 0.2 per cent slope $\left(\mathrm{L}_{1}\right)$ recorded higher per cent water saving of 36.89. The magnitudes of water saving in traditional levelling method $\left(\mathrm{L}_{3}\right)$ were 17.38 per cent over control. Also, laser land levelling method, $\mathrm{L}_{2}$ recorded water saving of 28.03 per cent and $\mathrm{L}_{1}$ registered23.61 per cent over traditional method of levelling, $\mathrm{L}_{3}$.

From the pooled data, it could be observed that the irrigation water used $\left(\mathrm{m}^{3} \mathrm{ha}^{-1}\right)$ and per cent water saved in border strip irrigation method $\left(\mathrm{I}_{1}\right)$ were considerably less $(1875.84$ $\mathrm{m}^{3} \mathrm{ha}^{-1}$ and $12.14 \%$ ) when compared to $2135.04 \mathrm{~m}^{3} \mathrm{ha}^{-1}$ in check basin irrigation $\left(\mathrm{I}_{2}\right)$. The similar trend was noticed with the depth of irrigation water applied. Considering the pooled effective rainfall during crop period, the total quantity of water required for groundnut was the least in $\mathrm{L}_{2}(50.20 \mathrm{~cm})$, followed by 51.20 and $56.30 \mathrm{~cm}$ in $\mathrm{L}_{1}$ and $\mathrm{L}_{3}$, respectively. The water requirement was the highest in $\mathrm{L}_{4}(60.90 \mathrm{~cm})$.

There was a significant difference observed in water requirement of groundnut as influenced by different land leveling methods. The pooled depth of irrigation water requirements were 15.7 and $16.7 \mathrm{~cm}$ in $\mathrm{L}_{2}$ and $\mathrm{L}_{1}$, respectively. The same were very much higher to the tune of 23.7 and $19.8 \mathrm{~cm}$ over control $\left(\mathrm{L}_{4}\right)$ and traditional plots $\left(\mathrm{L}_{3}\right)$, respectively. The highest per cent water saving was observed in both the laser land levelling treatments $\mathrm{L}_{2}$ andL $\mathrm{L}_{1}(28.00$ and $23.50 \%$, respectively) when compared with traditional levelling method $\left(\mathrm{L}_{3}\right)$ and $(40.50$ and $36.80 \%$, respectively) over control i.e. unlevelled plot $\left(\mathrm{L}_{4}\right)$. The water saving was mainly due to precise levelling in laser levelled plots leading to smooth and faster water front advance thereby quick uniform distribution of water. But in traditional levelling and unlevelled plots it was not so smooth. 
Table.1 Spatial and temporal variability of soil moisture $(0-15 \mathrm{~cm})$ due to rainfall events as affected by different land levelling methods

\begin{tabular}{|c|c|c|c|c|c|c|c|c|}
\hline \multirow{2}{*}{ Treatment } & \multicolumn{4}{|c|}{$\begin{array}{l}\text { Soil moisture content }(\%) \\
\text { after a day of rainfall event }\end{array}$} & \multicolumn{4}{|c|}{$\begin{array}{l}\text { Soil moisture content }(\%) \\
\text { after } 7 \text { days of rainfall event }\end{array}$} \\
\hline & $\mathrm{L}_{1}$ & $\mathrm{~L}_{2}$ & $\mathrm{~L}_{3}$ & $\mathrm{~L}_{4}$ & $\mathrm{~L}_{1}$ & $\mathrm{~L}_{2}$ & $\mathrm{~L}_{3}$ & $\mathrm{~L}_{4}$ \\
\hline 1 & 41.30 & 41.20 & 30.10 & 35.00 & 21.86 & 17.39 & 11.88 & 22.93 \\
\hline 2 & 43.80 & 41.20 & 41.70 & 44.40 & 24.54 & 13.20 & 12.04 & 11.64 \\
\hline 3 & 48.70 & 39.40 & 30.70 & 39.20 & 20.00 & 17.97 & 22.80 & 16.67 \\
\hline 4 & 40.40 & 39.60 & 49.20 & 18.60 & 17.69 & 15.97 & 19.85 & 10.77 \\
\hline 5 & 43.30 & 38.30 & 30.90 & 23.60 & 23.48 & 22.94 & 13.64 & 15.42 \\
\hline 6 & 48.70 & 38.90 & 33.20 & 34.50 & 15.38 & 19.95 & 18.94 & 21.28 \\
\hline 7 & 45.80 & 45.60 & 37.70 & 37.90 & 21.26 & 21.20 & 22.90 & 8.92 \\
\hline 8 & 49.10 & 45.20 & 28.00 & 25.10 & 15.89 & 24.38 & 9.97 & 7.71 \\
\hline Mean & 45.14 & 41.18 & 35.19 & 32.29 & 20.01 & 19.13 & 16.50 & 14.42 \\
\hline SD & 2.79 & 3.46 & 7.22 & 8.89 & 3.41 & 3.71 & 5.21 & 5.63 \\
\hline $\mathbf{C}_{\mathbf{u}}$ & 94.84 & 93.49 & 83.33 & 77.11 & 86.40 & 84.35 & 72.00 & 69.20 \\
\hline
\end{tabular}

Legend:

$\mathrm{L}_{1}$ : Laser land levelling method with 0.2 per cent slope,

$\mathrm{L}_{2}$ : Laser land levelling method with 0.4 per cent slope,

$\mathrm{L}_{3}$ : Traditional land levelling method

$\mathrm{L}_{4}$ : No land levelling (control)

Table.2 Quantity of water applied and per cent saving for groundnut production as influenced by different land levelling methods

\begin{tabular}{|c|c|c|c|c|c|}
\hline Treatment & $\begin{array}{c}\text { Average } \\
\text { time of } \\
\text { irrigation } \\
\left(h_{h a}^{-1}\right)\end{array}$ & $\begin{array}{c}\text { Total } \\
\text { quantity of } \\
\text { irrigation } \\
\text { water } \\
\text { applied } \\
\left(\mathrm{m}^{3} \mathrm{ha}^{-1}\right)\end{array}$ & $\begin{array}{l}\text { Total } \\
\text { depth of } \\
\text { irrigation } \\
\text { water } \\
\text { applied } \\
\text { (cm) }\end{array}$ & $\begin{array}{c}\text { Quantity of } \\
\text { irrigation water } \\
\text { saved in } \mathrm{L}_{1}, \mathrm{~L}_{2} \\
\text { and } \mathrm{L}_{3} \text { over control } \\
\left(\mathrm{L}_{4}\right) \text { and } \mathrm{I}_{1} \text { over } \mathrm{I}_{2} \\
\left(\mathrm{~m}^{3} \mathrm{ha}^{-1}\right)\end{array}$ & $\begin{array}{l}\text { Quantity of irrigation } \\
\text { water saved in } L_{1} \\
\text { and } L_{2} \text { over } \\
\text { traditional }\left(L_{3}\right) \text { and } I_{1} \\
\text { over } I_{2} \\
\left(\mathrm{~m}^{3} \mathrm{ha}^{-1}\right)\end{array}$ \\
\hline $\mathbf{L}_{1}$ & 8.3 & 1658.88 & 16.6 & $969.60(36.89)$ & $512.64(23.61)$ \\
\hline $\mathbf{L}_{2}$ & 7.8 & 1562.88 & 15.6 & $1065.60(40.54)$ & $608.64(28.03)$ \\
\hline $\mathbf{L}_{3}$ & 10.8 & 2171.52 & 21.7 & $456.96(17.38)$ & --- \\
\hline $\mathbf{L}_{4}$ & 13.1 & 2628.48 & 26.3 & -- & -- \\
\hline $\mathbf{I}_{1}$ & 9.4 & 1875.84 & 18.8 & $259.20(12.14)$ & $259.20(12.14)$ \\
\hline $\mathbf{I}_{2}$ & 10.7 & 2135.04 & 21.4 & -- & -- \\
\hline
\end{tabular}

Legend:

$\mathrm{L}_{1}$ : Laser land levelling method with 0.2 per cent slope, $\mathrm{I}_{1}$ : Border strip irrigation method

$\mathrm{L}_{2}$ : Laser land levelling method with 0.4 per cent slope, $\mathrm{I}_{2}$ : Check basin irrigation method

$\mathrm{L}_{3}$ : Traditional land levelling method

$\mathrm{L}_{4}$ : No land levelling (control) 


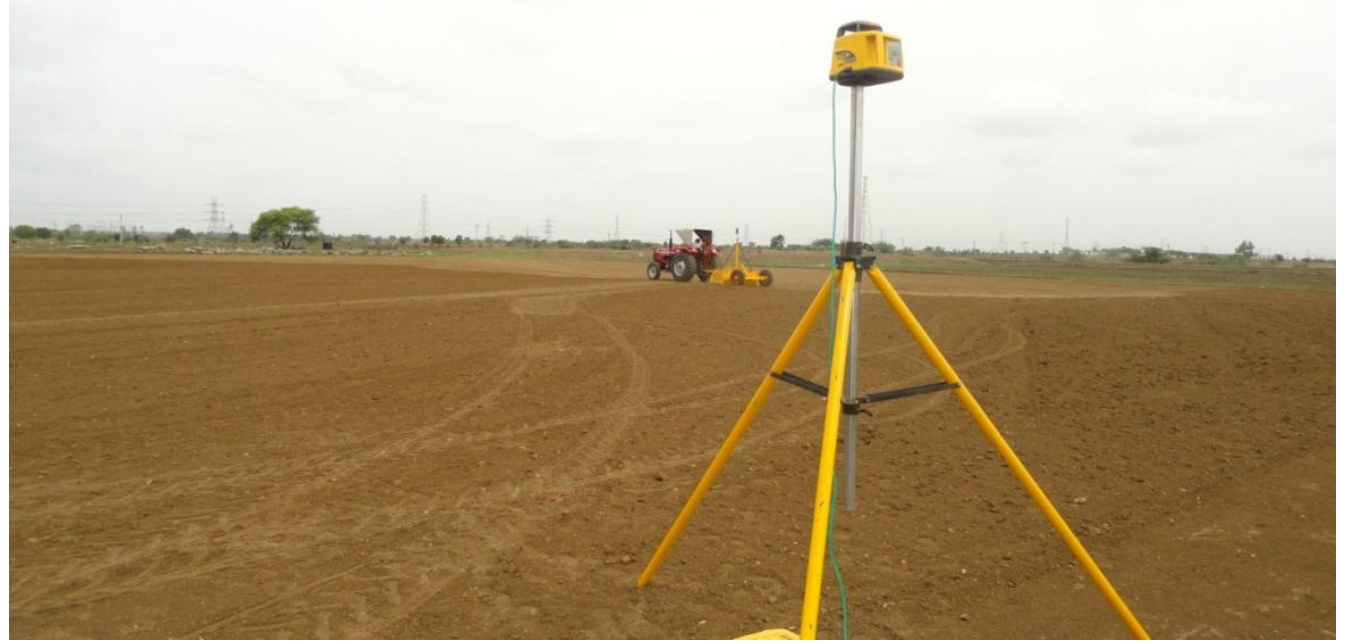

Fig.1 Operational view of the laser land leveling

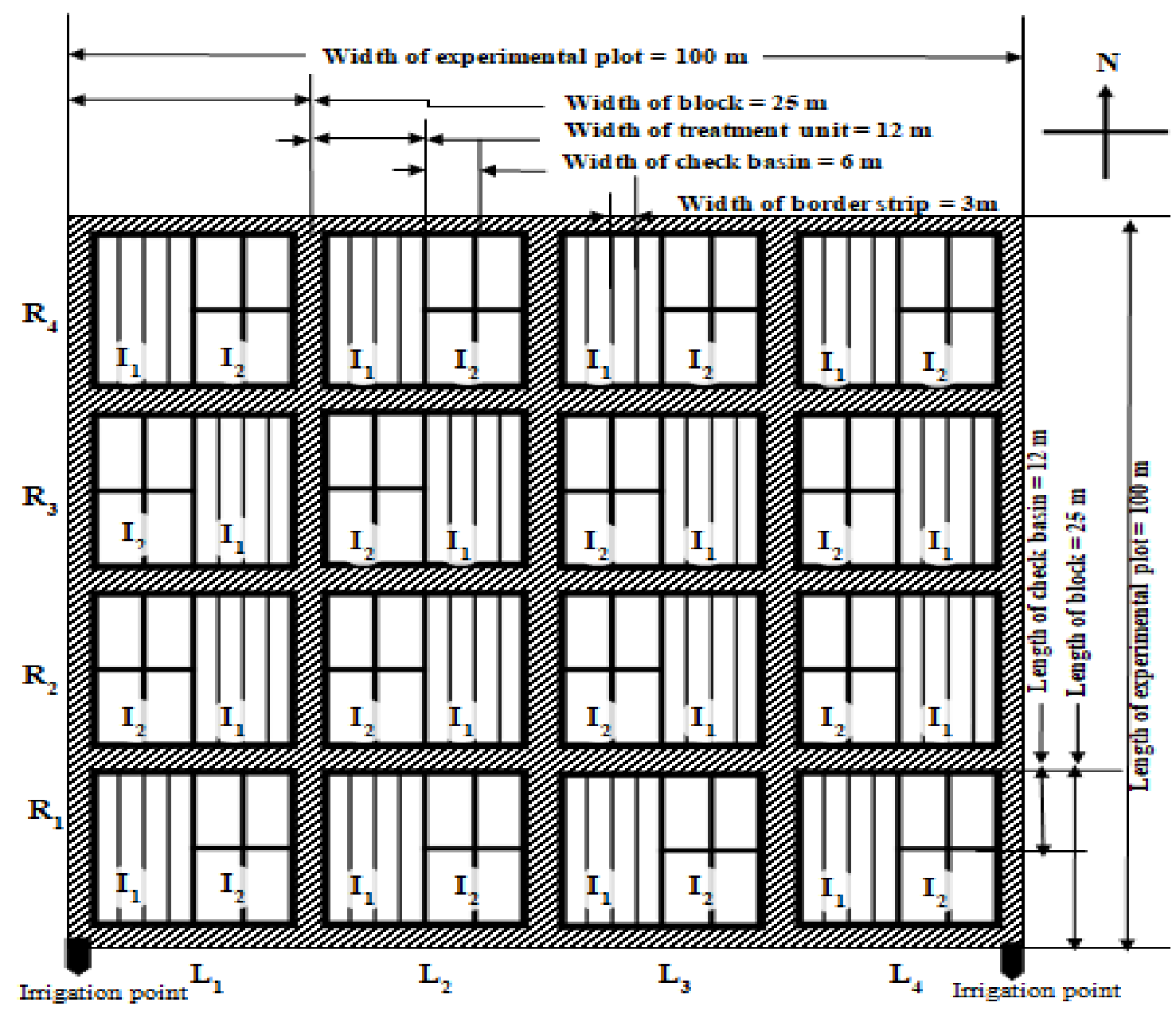

$R_{1}, R_{2}, R_{3}$ and $R_{4}$ are the replications for all treatments

$\mathrm{L}_{1}, \mathrm{~L}_{2}, \mathrm{~L}_{3}$ and $\mathrm{L}_{4}$ are the land levelling treatments, $\mathrm{I}_{1}$ and $\mathrm{I}_{2}$ are irrigation methods

Fig.2 Layout details of field experiment 
Whereas, water has to be applied so that the water reaches the high spots. The uniform distribution and reduced losses (Rajput and Patel, 2004, Abdullaev et al., 2007) in laser levelling plots also led to reduced depth of application and more saving of water. The irrigation time reduced considerably in levelled plots. The similar results on irrigation water requirement, depth and saving were reported by Rickman (2002), Jat and Sharma (2005), Aggarwal et al., (2010), Rajput and Patel (2010), Shahin et al., (2013) and Naresh et al., (2014). Thus, laser land levelling by saving water was proved to be a RCT in agricultural production.

There was uniform distribution of soil moisture and reduced losses in application of irrigation water in laserlevelling plots which led to reduced depth of application and more saving of water. The water front advance was smooth and faster in laser levelled plots with uniform distribution of water. Lowest quantity of irrigation water was used in laser levelled plot with 0.4 per cent slope followed by laser levelled plot with 0.2 per cent slope against traditional levelled plot and the highest quantity in control plot without levelling.

Significant quantity of irrigation water was saved in both laser land leveling techniques with 0.2 and $0.4 \%$ slopes as compared to traditional and nolevelling methods. Laser land levelling by saving water was proved to be a Resource Conservation Technology in groundnut production.

\section{Acknowledgement}

Authors are highly grateful to staff and Dean of College of Agricultural Engineering, UAS Raichur for their support and providing Laser leveller unit for the study. Thanks are also to officers of UAS Raichur for their help in successful completion of research study.

\section{References}

Abdullaev I., Mehmood Ul Hassan and Kahramon Jumaboev, 2007, Water saving and economic impacts of land levelling: the case study of cotton production in Tajikistan. Irrigation Drainage System, 21: 251-263.

Aggarwal, R., Samanpreetkaur, and Amarjeet Singh., 2010, Assessment of saving in water resources through precision land levelling in Punjab. Journal of Soil and Water Conservation., 9(3):182-185.

Anonymous, 2012. Agricultural Statistics at a Glance. Agricultural Statistics Division, Directorate of Economics and Statistics. Department of Agriculture and Cooperation, Ministry of Agriculture, Government of India, New Delhi.

Jat, M.L. and Sharma, S.K., 2005, Laser land levelling as precursor technology for RCTs. In: Agenda notes, $13^{\text {th }}$ Regional Technical Coordination Committee Meeting of the RWC. 6-8 February 2005, Dhaka, Bangladesh. pp. 19-20.

Naresh, R. K., Singh, S. P., Misra, A. K., Tomar, S. S., Pardeep Kumar, Vineet Kumar and Sanjeev Kumar, 2014, Evaluation of the laser levelled land levelling technology on crop yield and water use productivity in Western Uttar Pradesh. African of Agricultural Research, 9(4): 473-478.

Rajput, T.B.S. and Patel, N., 2010, Laser land levelling. Tech. Bull. No.72. Water Technology Centre, Indian Agricultural research Institute, New Delhi.

Rajput, T. B. S., Patel, N. and Agrawal, G., 2004, Laser levelling- a tool to increase irrigation efficiency at field level. Journal of Agricultural Engineering, 41(1): 20-25.

Rickman, J.F., 2002, "Manual for laser land leveling". Rice-Wheat Consortium Technical Bulletin Series 5. New Delhi110 012, India: Rice-Wheat Consortium 
for the Indo-Gangetic plains, p. 24.

Sattar, A., Khan. F. H. and Tahir, A.R., 2003, Impact of precision land levelling on water saving and drainage requirement. Journal of Agricultural Mechanization in Asia, Africa and Latin America, 34:
$39-41$.

Shahin, A., Jafar, H. and Seyed., M. J. A., 2013, Levelling as a tool for reducing water casualties in wheat fields. International Journal of Agricultural and Crop Sciences, 6(6): 296-299.

\section{How to cite this article:}

Kanannavar, P. S., P. Balakrishnan and Upadhyaya, S. K. 2020. Influence of Precise Land Development Technique on Soil Moisture Variability and Water Saving in Groundnut (Arachis hypogaea L.) Production. Int.J.Curr.Microbiol.App.Sci. 9(05): 2386-2392.

doi: https://doi.org/10.20546/ijcmas.2020.905.271 